\title{
AL-'UQUD AL-MURAKKABAH IMPLEMENTATION ON AKAD AL MURABAHAH WA ARRAHN AS A SHARIA BANKING PRODUCT INNOVATION
}

\author{
Bagya Agung Prabowo \\ Faculty of Law of Universitas Islam Indonesia \\ bagya.agung@uii.ac.id
}

\begin{abstract}
This article aims to determine the application of al-uqud al-murakkabah on akad al murabahah wa arrahn in sharia banking product innovation. This study uses analytic methods based on doctrinal content, by applying four types of legal approaches, namely: (i) historical / historical; (ii) Jurisprudence / philosophy; (iii) comparison; and (iv) analytical and critical. In addition, a harmonious approach is needed to align innovation of sharia banking products with sharia compliance principles. the conclusions in this study are: 1) The implementation of al-ququd almurakkabah as an innovation of Islamic banking products by the majority of Hanafiyah scholars, some opinions of Malikiyah scholars, Shafi'i scholars, and Hanbali are of the opinion that law is legal and permissible according to Islamic law, 2) The implementation of al-uqud al-murakkabah in the Murabahah wa ar Rahn contract is not in accordance with the principles of sharia compliance. Because the al Murabahah wa ar Rahn contract combines several contracts that cause usury or resemble usury, such as primarily combining the murabahah contract with the qardh contract, in addition to the wakalah contract and rahn contract.
\end{abstract}

Keywords: Al- 'Uqud al-Murakkabah; al Murabahah wa ar Rahn; Shariah Compliance

\section{Introduction}

\subsection{Background}

The development of innovation products in Islamic banking in various parts of the world is so rapid, not least in Indonesia. This is inseparable from the understanding of the majority of Muslims who begin to understand and realize that interest and capital whose results have been determined in advance (predetermined return) are usury that is prohibited by Islamic sharia. ${ }^{1}$

Sharia Banking is everything related to Sharia Banks and Sharia Business Units, including institutions, business activities, as well as ways and processes in carrying out their business activities. Sharia Banking business activities as a whole are based on sharia principles, economic democracy, and prudential principles. Islamic banks as a public trust institution (fiduciary financial institution) have a very strategic role in which the bank has a very noble vision and mission, namely as an institution that is tasked with carrying out the mandate of national development in order to achieve an increase in the lives of many people. ${ }^{2}$ Islamic banks also

\footnotetext{
1 Abdullah Saeed, Bank Islam dan Bunga, Studi Kritis dan Interprestasi Kontemporer tentang Riba dan Bunga, (Pustaka Pelajar, 2003), 2.

2 Nindyo Pramono, Hukum Perbankan 1, (Yogyakarta: PPS MMH UGM, 1997), 1.
} 
have a role as an intermediary financial, namely as an intermediary between parties who have excess funds (surplus of funds) with those who need funds (lack of funds). ${ }^{3}$

Along with the growth of sharia banking in Indonesia which is rapidly increasing, it has consequences to face increasingly complex challenges. Banking and Islamic financial institutions are required to be able to meet the needs of modern businesses by presenting innovative and more varied products and satisfying services.

Various types of Islamic banking products depend on the type of contract used by a product that is usually attached to the name of the product. As a consequence, all the provisions regarding the contract of a product apply to that product, then the validity of a product will depend on the validity of the product contract. Therefore, the substance of the contract is a pillar to build the contract. The substance of the contract is defined as the main purpose / objectives to be achieved with the contract being carried out. This is something that is the most substantial, because it will cause certain legal implications. The substance of the contract will be different for each different contract. For the murabahah contract, the substance of the contract is the transfer of ownership of the goods to the buyer by submitting the sale price. Murabahah contract is the sale and purchase of goods at the original price with additional agreed benefits. ${ }^{4}$ The characteristic of murabahah is that the seller must notify the buyer of the purchase price of the product and state the amount of profit added to the cost. ${ }^{5}$

Article 1 number 25 and Article 19 of Law Number 21 Year 2008 concerning Sharia Banking, states that Sharia Banks in their operations use contracts: wadi'ah, mudharabah, musyarakah, murabahah, istishna, salam, qardh, ijarah, ijarah muntahiya bittamlik, sharf, hawalah, kafalah, wakalah and other contracts that do not conflict with Islamic principles. From the perspective of the construction of these contracts, it indicates that a single contract is not responsive to contemporary financial transactions. The combination of the contract is now very necessary in creating Islamic banking and financial products to answer and meet the needs of an increasingly complex modern business.

Likewise in the innovation of Islamic banking products, including murabaha, Islamic banks are required to creatively innovate products. Likewise, the National Sharia Council (Dewan Syariah Nasional) is demanded to be active, creative and innovative in issuing edicts that are needed by the industry in accordance with the dynamics of the demands of the times but

\footnotetext{
Muhamad Djumhana, Hukum Perbankan di Indonesia (Bandung: Citra Aditya Bakti, 2003), 77.

4 Muhammad Syafi'i Antonio, Bank Syariah dari Teori ke Praktik (Jakarta: Gema Insani Press, 2001), 101.

5 Wiroso, Jual Beli Murabahah (Yogyakarta: UII Press, 2005), 13.
} 
do not deviate from sharia principles. As an innovation in banking products, Islamic banks can develop Islamic liens (rahn), whereas conventional banks cannot develop pawnings. Even today, Rahn is a fast growing business. Rahn is holding one of the borrower's property as collateral for the loan received.

Islamic banking observes that there are four elements that must be fulfilled in this pawning, namely the pawning party or the customer, the pawn recipient or the bank, collateral, and financing. Some Islamic banking places rahn as a separate product. In this case, rahn becomes an alternative to conventional pawn shops. If in a conventional pawnshop the customer bears interest, in rahn, that is not allowed. Furthermore, in rahn, which is taken from the customer is the cost of safekeeping, maintenance, guarding, and valuation. The cost of rahn and pawnshop interest, then, becomes the next differentiator between conventional pawnshops and sharia liens. Conventional pawnshop flowers multiply and always accumulate. Meanwhile, rahn fees are only paid once and are set in advance.

One important pillar to create innovation in Islamic banking and financial products in meeting the demands of modern society, is the development of al-'uqud al-murakkabah (hybrid contract) or multi-contract, because the form of a single contract is considered to be unable to respond to contemporary financial transactions. The concept of al-'uqud al-murakkabah (hybrid contract) continues to emerge and becomes an inevitable theory and concept. A number of books and scientific works also appeared discussing and formulating the theory of al-'uqud almurakkabah, especially scientific works from the Middle East. The al-'uqud al-murakkabah method (hybrid contract) is a necessity and is predicted to be superior in the development of Islamic banking products in the future.

Al-'uqud al-murakkabah (hybrid contract) in the development of innovation in Islamic banking products is an interesting topic to study, both in terms of theoretical and application in practice, because the contracts that underlie these transactions are growing and becoming more varied. One of them is al Murabahah wa ar Rahn gold sharia product.

The ideal implementation of al-uqud al-murakkabah in al Murabahah wa ar Rahn contract as an Islamic banking product innovation based on the Compilation of Sharia Economic Law and fatwa of National Sharia Board Number 04 / DSN-MUI / IV / 2000 concerning Murabahah has governed the obligation of Islamic banks to own goods customer needs in this context gold on murabaha financing so that the gold ownership status is clearly owned by the Islamic bank before being sold to the customer. The reality is that in murabaha financing operations, Islamic 
banks cannot buy goods needed by their customers one by one so that Islamic banks represent the purchase of goods directly to customers using al-'uqud al-murakkabah (hybrid contract), namely through the murabahah wa al wakalah contract. However, the transfer of power of attorney by the time of purchase agreement of these goods makes Islamic banks deviate from their obligation to own goods needed by customers before being sold to customers.

The ideal is the implementation of al-'uqud al-murakkabah in the Murabahah wa ar Rahn contract in accordance with the principles of sharia compliance. Where then the gold is handed over to the bank and then a qardh contract (debts) is combined with the rahn contract (pawn). Rahn is simply a debt or mortgage guarantee. Usually the contract used is the qardh wal ijarah contract, which is the loan agreement from the bank to the customer accompanied by the delivery of the mandate so that the bank keeps the collateral submitted. According to Sayyid Sabiq $^{6}$, the pawn contract is aimed at asking for trust and guaranteeing debt, not looking for profits and results. In reality, the act of utilizing goods is like a qiradh that streams benefits, and every form of qiradh that streams benefits is usury.

The implementation of al-'uqud al-murakkabah in al Murabahah wa ar Rahn gold pawn contract in Islamic banks uses a combination of five contracts namely murabahah, wakalah, qardh, rahn and ijarah. This study describes the implementation of al Murabahah wa ar Rahn gold in Islamic banking in Indonesia, reviewing the sharia principles contained in it, and offering a combination of contracts that are in accordance with sharia principles. From the results of the initial research, it was found that there was still an implementation of al-uqud al-murakkabah in the al Murabahah wa ar Rahn gold contract which was not in accordance with the principles of sharia compliance. The innovation of al Murabahah wa ar Rahn's products is considered very important to do research because it is the most widely used banking product in the present and future.

\subsection{Statement of the Problem}

Al-uqud al-murakkabah is a new term in contemporary jurisprudence, the appearance of multi-contract in various products is not all parties agree on it. There are some contemporary scholars who forbid and judge the concept of multi-covenant many of which contradict the hadiths of the Prophet. As one of the hadiths listed below: ${ }^{7}$

\footnotetext{
Sayyid Sabiq, Fiqih Sunnah (Beirut Publishing, 2013), 141-143

7 Muhammad Bin Ismail Al-Amir Ash-Shan'ani, Subulus Salam Syarah Bulughul Maram, Vol. 2
} 


\section{نهى عن صفقتين في صفقة واحدة}

Meaning: And from himself he said: "The Messenger of Allah forbid two buying and selling in one transaction".

From the hadith above there is an explanation of the Prophet's prohibition of two buying and selling in one transaction.

The majority of Hanafiyah scholars, some opinions of Malikiyah scholars, Syafi'iyah scholars, and Hanbali are of the opinion that hybrid contract law is legal and permissible under Islamic law. Scholars who allow the reason that the legal origin of the contract is permissible and valid, is not forbidden and canceled as long as there is no legal proposition that forbids or cancels it. ${ }^{8}$ Except combining two contracts that cause usury or resemble usury, such as combining qardh with another contract, because of the prohibition of hadith combining buying and selling and qardh. Similarly, combining buying and selling installments and buying and selling cash in one transaction.

In connection with the description above, the state of the art in the article is explained later. According to Ibn Taimiyah, the original law of all muamalat in the world is permissible except those which are forbidden by Allah and His Rasul, nothing is unlawful except those which are forbidden by Allah, and there is no religion except that which is prescribed. ${ }^{9}$ Nazih Hammad in the book al-'Uqûd al-Murakkabah fi al-Fiqh al-Islâmy writes, "The basic law in syara' is that it is permissible to carry out a hybrid contract transaction, as long as each contract that builds it when it is done independently the law is permissible and there is no argument that is forbid it. When there is an argument which forbids it, then the argument is not generally applied, but it excludes cases that are forbidden according to the argument". Therefore, the case is said to be an exception to the general rules that apply, namely regarding the freedom to enter into contracts and carry out agreed agreements. ${ }^{10}$ Likewise with Ibn al-Qayyim, he argues that the legal origin of the contract and terms is valid, except those which are canceled or prohibited by religion. ${ }^{11}$ Al-Syâtiby explains the difference between the original law of worship and muamalat. According to him, the original law of worship is to carry out (ta'abbud) what is ordered and not interpret the law. Whereas the original law of muamalat is to base its substance not on its practice (iltifât ila ma'âny). In the case of worship, there can be no discovery or change of what

\footnotetext{
Al-'Imrâni, Al-'uqûd al-Māliyah al-Murakkabah, 69

9 Ibn Taimiyah, Jami 'al-Rasil, j. 2, 317.

10 Nazîh Hammâd, al-'uqûd al-Murakkabah fi al-Fiqh al-Islâmy, 8.

11 Ibn al-Qayyim, I'l al-Muwaqqi'în, j. 1, 344.
} 
has been determined, while in the field of muamalat the opportunity to make changes and new discoveries is wide open, because the basic principle is that it is permissible (al-idzn) not to implement (ta'abbud). ${ }^{12}$

\subsection{Research Questions}

In this research, two key issues regarding implementation of al-'uqud al-murakkabah in the Murabahah wa ar Rahn contract as an innovation in Islamic banking which will be examined are: 1) How is the implementation of al-'uqud al-murakkabah as an innovation in Islamic banking products? 2) Is the implementation of al-'uqud al-murakkabah in the Murabahah wa ar Rahn contract in accordance with the principles of sharia compliance?

\subsection{Objectives of Study}

This research focuses on the problems that exist in the implementation of al-'uqud almurakkabah in the Murabahah wa ar Rahn contract as an innovation in Islamic banking. For ease of discussion, the overall objective of this research is divided into two categories:

General objectives: Overall objective of this research is to print out the implementation of al-'uqud al-murakkabah in the Murabahah wa ar Rahn contract as an innovation in Islamic banking.

Specific Objectives in this article are : 1) Identification of the extent of the implementation of al-'uqud al-murakkabah as an innovation in Islamic banking products, 2) Identify whether the implementation of al-'uqud al-murakkabah in the Murabahah wa ar Rahn contract is in accordance with the principles of sharia compliance.Research with a focus on the study of the application of al-uqud al-murakkabah in sharia banking product innovations is to identify, describe the implementation of al-'uqud al-murakkabah on the Murabahah wa ar Rahn contract as an innovation in Islamic banking products and analyze whether the implementation of al'uqud al -murakkabah in the contract al Murabahah wa ar Rahn in accordance with the principles of sharia compliance. To the knowledge of researchers, it has never been studied in depth by law researchers, both studies that lead to theoretical and practical levels. Previous studies discussing the innovation of Islamic banking products do not appear to be exhaustive by using the theory of al-'uqud al-murakkabah (hybrid contract) on the contract of al Murabahah wa ar Rahn until analysis based on fatwa of National Sharia Council Number 04 / DSN- MUI / IV / 2000

\footnotetext{
12 Al-Syâtiby, al-Muwâfaqat, j. 1, 284.
} 
concerning Murabaha. Therefore the affirmation of the originality of this study is intended to avoid repetition or duplication of a theme with the same focus of study. Duplication or repetition of such studies will not make a significant contribution to the development of legal science, both theoretically and practically.

\section{Methods}

Research will be conducted this research is the law where the law, the relevant statutory and case become the primary source. In other terms, such methods can also be called as a doctrinal or theoretical studies. ${ }^{13}$ Legal research using methods generally apply doctrinal fourpronged approach: i) the history / histories; ii) jurisprudence / philosophy; iii) comparison; and iv) an analytical and critical: ${ }^{14}$ Historical approach / History: 1) Used to determine how and why the existing regulations were adopted at that. ${ }^{15}$ 2)Aiming to identify its onset and progression of certain legal review. It is the method of detection, evaluation and synthesis of evidence and the evidence objectively and systematically to obtain the facts and concluded that the earlier incidents related. ${ }^{16}$ The work of academic, public documents, journal writing, seminar papers, law reports and more also completed the process of collecting data for this method.

The purpose of the Jurisprudence approach / philosophical approach is : 1) Examination of the ideas, theories and techniques peeled legal basis of current knowledge in multiple disciplines, is a set of related legal theory, a well-structured and systematic study of basic principles of law in the form of large, a scientific first principles exist in the legislation, is a fundamental concept and principles as a fundamental and central to the proposition of a law. ${ }^{17}$ 2) Contributing latest idea in answering questions related to the early principles of law, theory and set of laws provisions. Therefore this approach is used to study philosophy implementation of al-'uqud almurakkabah in the Murabahah wa ar Rahn contract as an innovation in Islamic banking products, and the suitability of the implementation of al-uqud al-murakkabah in the contract al Murabahah wa ar Rahn with the principles of sharia compliance. While the meaning of the analytical and Critical Approaches are: 1) A researcher can review and provide any suggestions for

13 Yakin Anwarul, Legal Research and Writing, Lexis Nexis, (Kelana Jaya, 1992), 10.

14 Sakina Shaikh Ahmad Yusoff, Graduate Thesis Proposal Preparation, New Graduate Program Modification Know Sem. II Session 2002/2003. 2002.

15 D.M. Walker, The Scottish Legal Systeman Introduction to the Study of Scots Law. 6 eds (Edinburg: W Green/Sweet \& Maxwell, 1992), 6.

16 Mahdi Zahraa, Research Methods for Law Postgraduate Student Overseas (Kuala Lumpur: Stilglow, 1998), 30.

17 D.M. Walker, The Scottish Legal System an Introduction to the Study of Scots Law. 6 eds, (Edinburg: W Green/Sweet \& Maxwell, 1992), 51. 
modifications, cancellation and replacement of law is weak and ineffective. ${ }^{18}$ 2) The real problem is identified that can be carried out efforts to prevent it, and make improvements to the implementation of al-'uqud al-murakkabah in the Murabahah wa ar Rahn contract as an innovation in Islamic banking, 3) Accomplish almost in all chapters in this thesis, complementing other approaches are also used in each chapter so as to formulate the direction of improvement, 4) Research is using two main techniques of data collection, namely the study of literature and field studies

\section{Results and Discussion}

In the context of this research, two main problems concerning implementation of al-'uqud al-murakkabah in the Murabahah wa ar Rahn contract as an innovation in Islamic banking products to be studied are: first, implementation of al-'uqud al-murakkabah in the Murabahah wa ar Rahn contract as an innovation in Islamic banking products; second, the suitability of the implementation of al-uqud al-murakkabah in the contract al Murabahah wa ar Rahn with the principles of sharia compliance.

In Islamic economic literature in Indonesia, it has long been developed the theory that sharia does not allow two contracts in one contract transaction (two in one). This prohibition is interpreted superficially and wrongly, thus narrowing the development of Islamic bank products. Though the sharia allows it in a very broad scope. It must be understood together that the prohibition of two in one is only limited in two cases according to the hadiths related to it. Two in one must not be extended to other problems which are irrelevant and do not fit the context.

Academics, sharia economists, sharia bankers and consultants must study deeply the views of scholars about the two in one contract and al-'uqud al-murakkabah, so that understanding of the design of sharia contracts can be more comprehensive, dynamic and not rigid. That rigidity can occur because of the shallowness of the methodological sharia in understanding the three hadiths of the Prophet which show the prohibition of using al-'uqud al-murakkabah (hybrid contract). The three hadiths contain three prohibitions, first the prohibition of bay 'and salaf, the prohibition of bai'ataini fi bai'atin, and the prohibition of shafqataini fi shafqatin. The three hadiths are always used as references by consultants and sharia practitioners about the two in one

\footnotetext{
18 Chartterjee, Methods of Research in Law (London: Old Bailey Press, 2000), 38.
} 
ban. But actually the ban only applies to two cases, because the purpose of the second and third hadith are the same, although the editors are different. ${ }^{19}$

The implementation of al-uqud al-murakkabah in the Murabaha wa ar Rahn contract is not in accordance with the principles of sharia compliance. Because the al Murabaha wa ar Rahn contract combines several contracts that cause us or resemble usury, such as primarily combining the murabahah contract with the qardh contract, in addition to the wakalah contract and rahn contract. The implementation of al-ququd al-murakkabah in the Murabaha wa ar Rahn al contract is al-ququd al-murakkabah mutanaqidhah (opposing contracts), where this form is prohibited in sharia.

Tracing of previous studies to determine the originality of this study is carried out by tracing the results of previous research (literature review), both those that have been done by researchers from within the legal disciplines themselves and outside the legal sciences, especially science social Sciences. Some relevant research that has been successfully collected by researchers as a comparison of previous studies is to show the originality of this study.

Harnia $^{20}$ in 2012 conducted a study with the title "Analysis of the Application of Murabaha on the Financing of Muamalat Sharia Housing (Study at Muamalat Makassar Bank)." The results of his research are Sharia Housing Financing is one of the Bank Muamalat products to channel financing in home ownership using the Murabahah Bil Wakalah contract, a sale and purchase agreement where the customer submits an application for financing to the bank, then the bank buys the house and the bank resells to customers in installments.

Nevi Hasnita ${ }^{21}$ in 2014 conducted a study entitled "Concept and Form of Multi-Contract (Hybrid Contract) in the Fatwa of the National Sharia Council - Indonesian Ulama Council (DSN-MUI)". The result of his research is explaining the concept of multi-contract and multicontract products found in Islamic banking. Multi-contract in Islamic banking is guided by the DSN-MUI Fatwa as an operational basis, explaining also the forms of multi-contract that are allowed and prohibited in muamalah activities. The multi-contract explained by Nevi Hasnita focused more on the generality of the concept and multi-contract form in the DSN-MUI fatwa.

19 Zaenuddin Ali, Hukum Perbankan Syariah (Jakarta: Sinar Grafika, 2008), 36.

20 Harnia, Analisis Penerapan Murabahah pada Pembiayaan Hunian Syariah Muamalat (Studi pada Bank Muamalat Makassar), Skripsi, (Makassar: Fakultas Syariah dan Hukum UIN Alaluddin Makassar, 2012).

21 "Konsep dan Bentuk Multi Akad (Hybrid Contract) Dalam Fatwa Dewan Syariah Nasional Majelis Ulama Indonesia (DSN MUI),"Jurnal Dusturiyah 2020, (2014). 
Dara Setianti Kania ${ }^{22}$ in 2016 conducted a study entitled "Suitability of Mortgage Funding Mechanism for Mortgage Products According to DSN fatwa in Surabaya Jatim Syariah Bank". The results of his research are the appropriateness of supervision and handling the collectibility of Murabahah Financing for KPR Products according to the DSN MUI Fatwa in Syariah Jatim Bank seen from six indicators, namely prices, fines, guarantees of underwriting of problematic murabahah financing and bad financing adjusted to the MUI DSN fatwa. 04 / DSN-MUI / IV / 2000 concerning Murabahah, No. 13 / DSN-MUI / IX / 2000 concerning Murabahah Advances, No. 17 / DSN-MUI / IX / 2000 concerning Sanctions for Able Customers who can Postpone Payment, No. 47 / DSN-MUI / II / 2005 concerning Settlement of Murabahah Receivables for Unable to Pay Customers, No.48 / DSN-MUI / II / 2005 concerning Rescheduling of Murabahah Claims.

Ummi Kalsum and Eka Rizky Saputra ${ }^{23}$ in 2016 conducted a study entitled "Inclusion of Wakalah Agreement on Murabahah Funding (Study at BNI Syariah Branch Kendari)". The results of his research are in the perspective of Islamic economics, inclusion of wakalah contract on murabaha financing is included in the type of merging of the contract that is permitted, but each harmony and conditions in these two contracts must be fulfilled if it is to be combined so as not to fall into the prohibited muamalah. Like, the objects that are traded and goods traded are the full property of the parties. However, in practice, murabaha financing, while the wakalah that occurred at BNI Syariah Kendari Branch has aborted one of the pillars and conditions in the sale of goods that are not traded and the goods are not the full property of the parties in the contract so the submission of the object cannot do. Buying and selling of this kind is prohibited because it is included in the category of selling goods that are not owned, selling goods that are not owned by themselves and setting profits on goods that are not yet under authority.

Based on the results of research conducted by the authors above, when compared with the research that will be conducted by the author there is no equal both in terms of the scope of the object, subject, approach, methodology and paradigm used. This difference shows where the author has research authenticity because it contains new things in it. Therefore, researchers believe that this research is original and has never been done by anyone else.

22 Dara Setianti Kania, Kesesuaian Mekanisme Pembiayaan Murabahah Produk KPR Menurut fatwa DSN di Bank Jatim Syariah Surabaya, Skripsi, (Surabaya: Fakultas Ekonomi dan Bisnis, Universitas Airlangga, 2016).

23 Ummi Kalsum, Eka Rizky Saputra, "Penyertaan Akad Wakalah pada pembiayaan Murabahah (Studi di BNI Syariah Cabang Kendari),” Li Falah, Jurnal Studi Ekonomi dan Bisnis Islam I, No. 1 (2016). 


\section{Conclusion}

Based on the analysis and discussion above, the following conclusions can be formulated: 1) The implementation of al-ququd al-murakkabah as an innovation of Islamic banking products by the majority of Hanafiyah scholars, some opinions of Malikiyah scholars, Shafi'i scholars, and Hanbali are of the opinion that law is legal and permissible according to Islamic law. Scholars who allow the reason that the legal origin of the contract is permissible and valid, is not forbidden and canceled as long as there is no legal proposition that forbids or cancels it. Moreover, because the form of a single contract is considered to be unable to respond to contemporary financial transactions. 2) The implementation of al-uqud al-murakkabah in the Murabahah wa ar Rahn contract is not in accordance with the principles of sharia compliance. Because the al Murabahah wa ar Rahn contract combines several contracts that cause usury or resemble usury, such as primarily combining the murabahah contract with the qardh contract, in addition to the wakalah contract and rahn contract. The implementation of al-ququd almurakkabah in the Murabahah wa ar Rahn al contract is al-ququd al-murakkabah mutanaqidhah (opposing contracts), where this form is prohibited in sharia.

\section{References}

Al-'Imrâni. Al-'uqûd al-Māliyah al-Murakkabah.

Al-Syâtiby. al-Muwâfaqat, j. 1 .

Al-Qayyim, Ibn. I'l al-Muwaqqi'în, j. 1 .

Ali, Zaenuddin. Hukum Perbankan Syariah. Jakarta: Sinar Grafika, 2008.

Antonio, Muhammad Syafi'i. Bank Syariah dari Teori ke Praktik. Jakarta: Gema Insani Press, 2001.

Anwarul, Yakin. Legal Research and Writing, Lexis Nexis. Kelana Jaya, 1992.

Ash-Shan'ani, Muhammad Bin Ismail Al-Amir. Subulus Salam Syarah Bulughul Maram Vol. 2.

Chartterjee. Methods of Research in Law. London: Old Bailey Press, 2000.

Djumhana, Muhamad. Hukum Perbankan di Indonesia. Bandung: Citra Aditya Bakti, 2003.

Fatwa Dewan Syariah Nasional No: 04/DSN/MUI/IV/2000 tentang Pembiayaan Murabahah

Hammâd, Nazîh. al-'uqûd al-Murakkabah fi al-Fiqh al-Islâmy.

Harnia. Analisis Penerapan Murabahah pada Pembiayaan Hunian Syariah Muamalat (Studi pada Bank Muamalat Makassar), Skripsi. Makassar: Fakultas Syariah dan Hukum UIN Alaluddin Makassar, 2012. 
Kalsum, Ummi, and Eka Rizky Saputra. "Penyertaan Akad Wakalah pada Pembiayaan Murabahah (Studi di BNI Syariah Cabang Kendari)", Li Falah, Jurnal Studi Ekonomi dan Bisnis Islam 1, No. 1(2016).

Kania, Dara Setianti. Kesesuaian Mekanisme Pembiayaan Murabahah Produk KPR Menurut fatwa DSN di Bank Jatim Syariah Surabaya, Skripsi. Surabaya: Fakultas Ekonomi dan Bisnis, Universitas Airlangga, 2016.

Kitab Undang-Undang Hukum Perdata (KUHPerdata)

"Konsep dan Bentuk Multi Akad (Hybrid Contract) Dalam Fatwa Dewan Syariah Nasional Majelis Ulama Indonesia (DSN MUI),": Jurnal Dusturiyah Vol 2020 (2014).

Pramono, Nindyo. Hukum Perbankan 1.Yogyakarta;PPS MMH UGM, 1997.

Sabiq, Sayyid. Fiqih Sunnah. Beirut Publishing, 2013.

Saeed, Abdullah. Bank Islam dan Bunga, Studi Kritis dan Interprestasi Kontemporer tentang Riba dan Bunga. Pustaka Pelajar, 2003.

Taimiyah, Ibn. Jami 'al-Rasil, j. 2.

Undang-Undang No. 8 Tahun 1999 tentang Perlindungan Konsumen

Undang-Undang No. 10 Tahun 1998 tentang Perubahan Undang-Undang No. 7 Tahun 1992 tentang Perbankan

Undang-Undang No. 21 Tahun 2008 tentang Perbankan Syariah

Undang-Undang No. 21 Tahun 2011 tentang Otoritas Jasa Keuangan (OJK)

Walker, D. M. The Scottish Legal System an Introduction to the Study of Scots Law. 6 eds. Edinburg: W Green/Sweet \& Maxwell, 1992.

Wiroso. Jual Beli Murabahah. Yogyakarta: UII Press, 2005.

Yusoff, Sakina Shaikh Ahmad. Graduate Thesis Proposal Preparation, New Graduate Program Modification Know Sem. II Session 2002/2003. 2002.

Zahraa, Mahdi. Research Methods for Law Postgraduate Student Overseas. Kuala Lumpur: Stilglow, 1998. 